\title{
Non-timber Forest Products of Mauritia flexuosa L. f.: Loss or Permanence in Quilombola Communities of Southern Amazon?
}

While Non-timber forest products are relevant to conservation and development, there are diverse drivers that have a complex impact on their use and traditiona ecological knowledge (TEK). The erosion of TEK and its causes were evaluated on buriti (Mauritia flexuosa L. f.) in Quilombola communities in Brazil, by using ethnographic and ethnobotanical methods, including snow ball, 23 interviews, and participant observation. Informants reported 15 different uses of buriti divided into five categories (food, animal feed, handicrafts, construction, and ornamental); however, only five uses were actively performed until the end of this study. Differences between knowledge and uses of buriti could be attributed to proximity to urban centers, public policies for livestock production, and decreasing interest in handcraft manufacturing by using local resources. Therefore, it is important to ensure that knowledge and traditional practices in rural communities are combined for the socioeconomic benefits of rural/urban connection. Additionally, public policies need to focus on the local potential associated with biodiversity - including buriti - and with the TEK associated, instead of encouraging exotic cultures that significantly decrease biological and cultural diversity.

\section{Produtos Florestais Não Madeireiros de Mauritia flexuosa L. $f$.: Perda ou Permanência em Comunidades Quilombolas do Sul da Amazônia?}

\begin{abstract}
Os produtos florestais não madeireiros são relevantes para o desenvolvimento e o desenvolvimento de recursos ecológicos tradicionais (CET). A erosão do CET e suas causas foram avaliadas para o Buriti (Mauritia flexuosa L. f.) Nas comunidades quilombolas no Brasil, através da utilização de métodos etnográficos e etnobotânicos, incluindo a bola de neve, 23 entrevistas e observação participante. Os informantes relataram 15 usos diferentes de buriti divididos em cinco categorias (alimentos, ração animal, artesanato, construção e ornamentais); No entanto, as cinco utilizações foram promovidas ao final deste estudo. As diferenças entre o conhecimento e o uso do buriti podem ser atribuídas à proximidade dos centros urbanos, as políticas públicas de produção pecuária e a redução do interesse na fabricação artesanal através da utilização de recursos locais. As proteções são importantes para os benefícios sociobólicos da conexão rural / urbana. Além disso, como as campanhas públicas devem estar se associando ao TEK e à presença de Buriti nas comunidades da Amazônia, em vez de promover culturas exóticas que reduzem a diversidade biológica e cultural.
\end{abstract}

Keywords: Etnobotânica; Erosão do Conhecimento; Políticas Públicas; CET; PFNM.

\section{Nilo Leal Sander (iD)}

Universidade do Estado de Mato Grosso, Brasil http://lattes.cnpq.br/6241511798904038

http://orcid.org/0000-0001-9856-6819

nilosander@gmail.com

\section{Carolina Joana da Silva (iD)}

Universidade do Estado de Mato Grosso, Brasil

http://lattes.cnpq.br/5253872582067659

http://orcid.org/0000-0003-0517-1661

ecopanta@terra.com.br

\section{Joari Costa de Arruda (it}

Universidade do Estado de Mato Grosso, Brasil http://lattes.cnpq.br/7417323137885131 http://orcid.org/0000-0001-8813-983X arrudajcbio@gmail.com

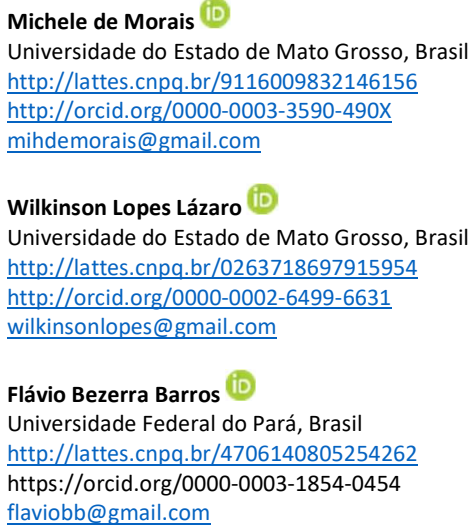

Maria Teresa Pulido Silva

Universidad Autónoma del Estado de Hidalgo, México

mtpulido@yahoo.com
Referencing this:

SANDER, N. L.; SILVA, C. J.; ARRUDA, J. C.; MORAIS, M.; LÁZARO, W. L.; BARROS, F. B.; SILVA, M. T. P.. Non-timber Forest Products of Mauritia flexuosa L. f.: Loss or Permanence in Quilombola Communities of Southern Amazon?. Revista Ibero-Americana de Ciências Ambientais, v.9, n.1, p.43-55, 2018. DOI: http://doi.org/10.6008/CBPC21796858.2018 .001 .0004 


\section{INTRODUCTION}

While Non-timber forest products (NTFP) has been suggested as an important alternative to conciliate conservations and development, at the same time currently there are a notorious disuse of them, erosion of their traditional ecological knowledge (TEK), and abandonment. This is an important fact has not been analyzed in the literature, in spite of their notorious potential consequences on livelihood, local development, and nature conservation. In this context, local studies provide relevant information to a better understanding of this phenomenon. The current paper analyzes the changes in use, loss of TEK and their relationship with diverse drivers related to external factors. We focus on the palm Mauritia flexuosa, one of the most important NTFP in the amazon, in terms of number of uses (Martins et al. 2012), geographical range (Steegel et al. 2013), current and past users (Santos \& Coelho-Ferreira 2012, Barros \& Da Silva 2013, Gilmore et al. 2013, Arruda et al. 2014). Additional studies to local and regional scales can help to understand the phenomena coined by Pulido \& Coronel-Ortega (2015) as "use and disuse of non-timber forest products".

Traditional ecological knowledge is important for maintaining sustainable development and biodiversity (Reyes-García et al. 2013, 2014). Studies on TEK have been conducted for several years, but changes in knowledge have not received special attention. These studies have reported information on practices and beliefs accumulated and transmitted through generations and aimed to identify the relationships of humans with the environment (Berkes et al. 2000). Knowledge can change, whereas the rate of change depends on the location and interests of human communities (Berks 1999, Benz et al. 2000, ReyesGarcía et al. 2013). The loss of TEK mostly affects species that are historically associated with human survival and is mainly caused by changes in land use and management, community integration with the local market, public policies, technology advancement, and climate change (Benz et al. 2000, Reyes-García et al. 2005, Gray et al. 2008, Gómez-Baggethun et al. 2010, Reyes-García et al. 2014, Litre et al. 2014). However, it is not sufficiently documented whether these changes can affect human welfare or cultural characteristics (World Bank 2013, Shackleton \& Pandey 2014). Therefore, it is essential to better understand knowledge erosion and the underlying causing factors.

The family Arecaceae includes Amazon-wide hyperdominant palm tree species that support several human communities, providing important ecosystem services (Manzi \& Coomes 2009, Santos \& CoelhoFerreira 2011, Steegel et al. 2013, Gilmore et al. 2013, Arruda et al. 2014). A total of 2,700 palm tree species in 240 genera were cataloged worldwide, of which 282 species in 38 different genera are found in Brazil, 122 are considered endemic (Lorenzi et al. 2010, Leitman et al. 2015). The main palm tree species used by human populations in Brazil are Euterpe oleraceai, Orbignya olerata, Astrocaryum aculeatum, and Mauritia flexuosa (Gonzalez-Perez et al. 2012, Milanesi et al. 2013, Barros \& Da Silva 2013). However, Arecaceae is affected by deforestation and indiscriminate use in Brazil (Coradin \& Lleras 1988, Byg \& Balsley 2006, Arruda et al. 2014).

Among the 40 different palm tree species found in Mato Grosso, buriti (also known as 'miriti' in Brazil, 'aguaje' in Peru, 'canangucha' and 'moriche' in Colombia, 'moretes' in Ecuador, and 'palma real' in Bolivia) is a long-life, arboreal, and dioecious species found in tropical wetlands and swamps in South America. In Brazil, 
it appears either isolated or in groups in the savanna, the Amazonian Forest, and to a lesser extent, the Pantanal wetland. Buriti provides several raw materials such as palm hearts and fruits for feeding, rafters for construction, leaves for coverage and forage, fibers for handicrafts, and oil for biotechnology products and cosmetics (Vasthatz \& Gentry 1989, Carrera 2000, Delgado et al. 2007, Santos \& Coelho-Ferreira 2012, Gilmore et al. 2013, Arruda 2013, Koolen et al. 2013). Buriti is used by several Brazilian and Pan-Amazonian communities, including the Quilombolas and Ribeirinhos (Delgado et al. 2007, Manzi \& Coomes 2009, Horn et al. 2012, Gilmore et al. 2013, Barros \& Da Silva 2013). Studies on the use and management of palm trees by indigenous people and traditional communities may provide answers about its conservation and permanence in the ecological-cultural system.

The Quilombolas are descendants of African slaves who were shipped to Brazil by the Portuguese in the mid- $17^{\text {th }}$ century and who have retained a traditional lifestyle. Currently, there are approximately 2,600 quilombos in Brazil, and their culture is significantly affected by changes in the environment and society, leading to the loss of some original characteristics (Salles 1971, Volpato 1996, Thorkildsen 2014, Arruda et al. 2014, Fernandes 2015, Fundacão Palmares 2016).

In this study, we focused on the Quilombolas in Vila Bela da Santíssima Trindade, Mato Grosso, a zone of ecological tension between the two largest Brazilian biomes, the Amazonian Forest and Cerrado in order to investigate the interactions with buriti uses based on ethnobotanical approach (Radambrasil 1982). Focused on buriti, our objective was study the TEK and their change along the time and their relationship with social, ecological and cultural drivers. Our hypothesis is that the Quilombola people have a deep TEK about this palm because they have had five centuries to generate, transmit and learn about the uses of this species. However, we expect that their TEK and/or uses and management have been eroded in the last decades because of the vertiginous economic changes in Amazonia.

\section{METHODS}

\section{Study Area and Communities}

The study was performed in August 2012 and October 2013 in three Quilombola communities in Vila Bela, Trindade County $\left(14^{\circ} 02^{\prime}\right.$ South and $16^{\circ} 14^{\prime}$ West, $59^{\circ} 24^{\prime}$ South and $60^{\circ} 33^{\prime}$ West), Mato Grosso State, Brazil. The first author resided in the study area for one week per month for 14 months to better approach and understand the local people. Along the time, their links with local people were deeper and stronger.

The climate in this area is humid tropical or subtropical based on the Koppen climate classification system with an average annual temperature of $23.9-25.6^{\circ} \mathrm{C}$ and four months of continuous drought. The average annual precipitation is $1,500 \mathrm{~mm}$, but exceeds $3,500 \mathrm{~mm}$ in areas with stronger rainfall. The maximum rainfall occurs in December, January, and February. The county is located in the upper Guapore River basin between Savana and the Amazonian Forest, where mountains and lowlands result in a place with high levels of biological diversity. 
The study communities were Boqueirão, Retiro, and Casalvasco Manga (Fig. 1) with a total of 20, 25, and 15 people, respectively, distributed in nine, twelve, and five families, respectively. The low number of inhabitants in these communities is related to historical changes, whereas in the past, each of these areas belonged to a single family. When the patriarchs passed away, these lands were distributed among their descendants.

My father owned the entire land. After his death, it was distributed to his children, and now there are grandchildren too (Female, 60 years old).

Boqueirão, Retiro, and Casalvasco Manga belonged to two families. All my siblings, nieces, and nephews live in Casalvasco Manga, and here (Retiro). Most of them here are my nieces and nephews (Female, 76 years old).
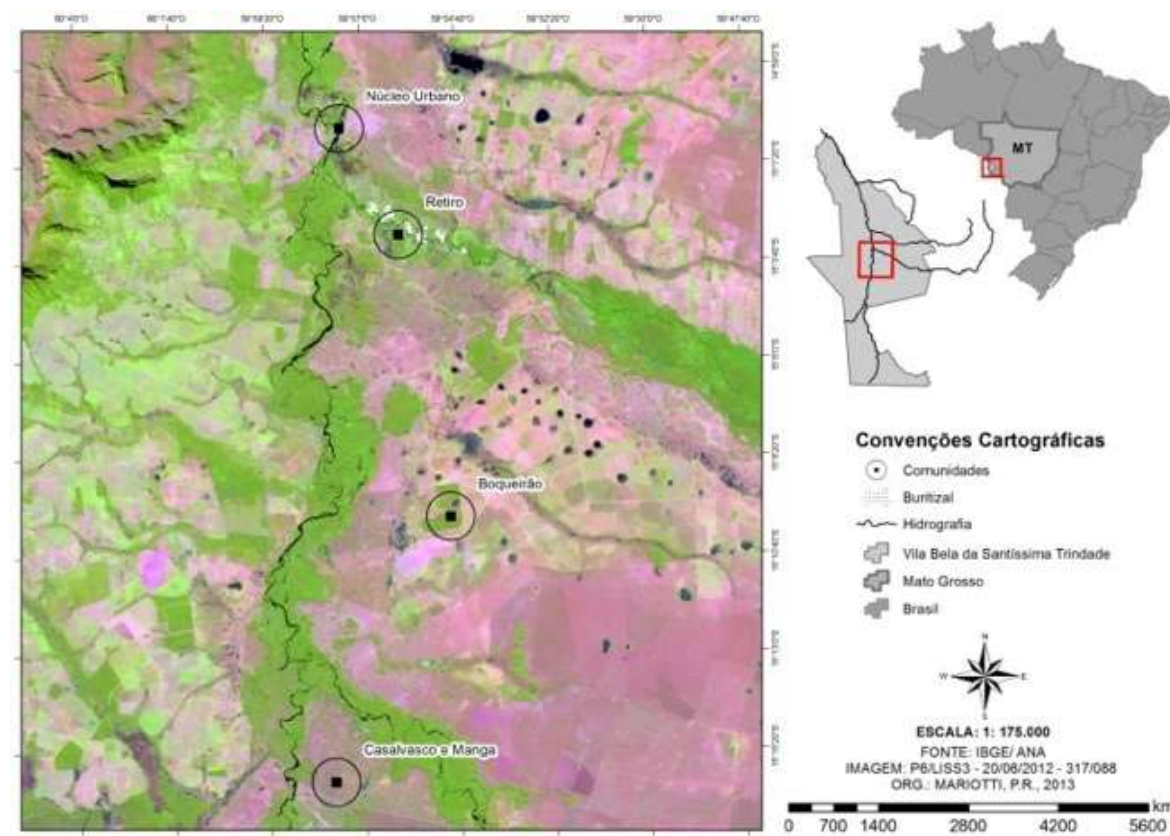

Convençōes Cartográficas

- Comuridades

Bunzaal

น- Hidrografia

Vila Beia da

Mats Gross

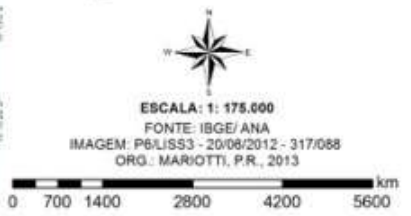

Figure 1. Localization of the study communities (Boqueirão, Retiro, and Casalvasco and Manga) and the urban center of Vila Bela de Santíssima Trindade.

All three communities were inhabited by from African descendent since the colonial period when Vila Bela was the capital of Mato Grosso State. This black population was enslaved to work in the gold mines, in assembling the then capital and the defense of this border region. Then, it was forsaken by white people, who went to Cuiabá (1920) to build the current capital of Mato Grosso. And this historical moment that formed several free black communities, including those of which descended the three communities studied in this research (Boqueirão, Casalvasco and Manga, Retiro). The people of this community self entitle Quilombo (descendants of Africans). The three communities are have been recognized by the Fundação Palmares (Brazilian entity responsible for reviewing the Quilombola rights) and struggle for land rights through the National Institute of Colonization and Agrarian Reform. The distance between the Boqueirão, Retiro, and Casalvasco Manga communities and the urban center is $17.7 \mathrm{~km}, 35.4 \mathrm{~km}$, and $43.5 \mathrm{~km}$, respectively (Arruda 2013).

In the 70s and 80 s, the study area was connected to southeastern and southern Brazil through paved roads, whereas public policies encouraged southerners to relocate and purchase land at a relatively low cost. The expansion of agriculture towards the Amazon and the incorporation of Brazil to the international food 
market led to changes in the patterns of land use. Forest and savanna landscapes were converted to pastures, and livestock farming was enforced. Vila Bela da Santíssima Trindade has the second highest number of cattle in Mato Grosso and the sixth in the country (IBGE 2015). Therefore, Quilombola communities underwent several economic, social, ecological, and cultural changes.

\section{Interviews}

To better understand the local use of buriti and related culture, qualitative and quantitative methods of ethnobotanical data analysis and collection, such as structured and semi-structured interviews and participant observations were performed (Geertz 1989). All the participants read the terms and content of this study and signed a typical consent agreement.

In order to investigate the TEK, use, and cultural importance of buriti, we selected by the snowball method (Bernard 2006) and interviewed 23 informants (18 men and five women) between 27 and 82 years of age that resided in the study area for 5-60 years. They were distributed in the urban region (2), Retiro community (10), Boqueirão community (8), and Casalvasco Manga community (3). The number of informants was delimited by the collector curve, which was stabilized at the $22^{\text {nd }}$ interview.

The informant diversity index (IDs) that shows the number of informants that use a specific species was calculated as follows (Byg \& Balsley 2001):

$$
I D=1 / \sum P_{i}^{2},
$$

where $P_{i}$ is the contribution of informant $i$ to the total knowledge of species $s$. This is, the number of uses of species $s$ mentioned by the informant $i$ divided by the total number of uses reported by the informants as a whole. Therefore, ID ranges between zero and the number of informants that use the species.

\section{RESULTS AND DISCUSSION}

\section{Quilombolas and Buriti Use}

The results showed that 15 products can be developed using different parts of buriti (stipes, leaves, and fruits) divided into five usage categories: handicraft, food, construction, feed, and ornamental (Table 1). These different products were used for their livelihood, as a source of food and utensils that helped in his field, creating some animals and harvest of fruits available in the forest. These also served as a source of exchange with other products not produced or created. A total of four different uses were identified for the fruit, of which the most common was the juice (7). Candy, oil, and animal feed were mentioned only by a single informant. Barros \& Da Silva (2013) indicated the importance of the buriti fruit for the AbaetetubaPará community, because it is consumed in breakfast due to its high levels in vitamins $A$ and $C$, carotene, calcium, magnesium, and phosphorus. The Enawene-Nawe community in Mato Grosso also consumes the fruit combined with honey (Santos \& Antonini 2008).

The buriti fruit is a source of income for many riverside and indigenous communities and is consumed by approximately $60 \%$ of the population (Santos \& Coelho-Ferreira 2012, Barros \& Da Silva 2013, Gilmore 
2013). From 1993 to $1995,148.8$ tons per month were sold in the lquitos market, Peru, whereas 40 tons per year were traded in the Leticia market, Colombia (Pulido \& Cavelier 2001, Gilmore et al. 2013). In Iquitos, 124 buriti sacks (approximately one million fruits) are sold per day at a price range of US\$1.09 to US\$12.72 per sack (Delgado et al. 2007, Koolen et al. 2013). In Roca Fuerte County, Peru, buriti fruit commercialization represented the third biggest average source of household income from January 2012 to December 2012 (Manzi \& Coomes 2009).

Table I. Frequency of buriti (Mauritia flexuosa L. f.) usages and used plant parts by three quilombola communities in Vila Bela de Santíssima Trindade (23 informants).

\begin{tabular}{|c|c|c|c|c|c|}
\hline Usage & Plant Part & Frequency (\%) & Harvest Season & Harvest Method & $\begin{array}{l}\text { Production } \\
\text { Leader }\end{array}$ \\
\hline \multicolumn{6}{|l|}{ Food } \\
\hline Juice & Fruit & 30 & Sept to July & Bunch drop & Woman \\
\hline Candy & Fruit & 4 & Sept to July & Bunch drop & Woman \\
\hline Oil & Fruit & 4 & Sept to July & Bunch drop and/or Soil gathering & Family \\
\hline \multicolumn{6}{|c|}{ Animal feeding } \\
\hline Food & Fruit & 4 & Sept to July & Bunch drop and/or Soil gathering & Man \\
\hline \multicolumn{6}{|l|}{ Handicraft } \\
\hline Apá & Leaf & 78 & Year-round & Young leaf pruning & Man \\
\hline Sieve & Leaf & 43 & Year-round & Young leaf pruning & Man \\
\hline Baquité & Leaf & 26 & Year-round & Young leaf pruning & Man \\
\hline Wickerwork & Leaf & 30 & Year-round & Young leaf pruning & Man \\
\hline Jacá basket & Leaf & 4 & Year-round & Young leaf pruning & Man \\
\hline Toy & Leaf & 13 & Year-round & Young leaf pruning and/or Old stalk removal & Man \\
\hline Stopper & Stipe & 21 & Year-round & Old stalk removal & Man \\
\hline \multicolumn{6}{|l|}{ Construction } \\
\hline Lift & Stipe & 26 & Year-round & Cut directly from the tree & Man \\
\hline Roof & Leaf & 30 & Year-round & Young leaf pruning & Man \\
\hline Canoe & Stipe & 8 & Year-round & Cut directly from the tree & Man \\
\hline \multicolumn{6}{|l|}{ Ornamental } \\
\hline Decoration & Plant & 4 & Year-round & Seedling Planting & Family \\
\hline
\end{tabular}

Only one informant mentioned the collection and use of buriti for its juice, whereas all others mentioned the physical difficulties in buriti fruit collection directly from the palm-trees, mainly due to the low number of young people in the communities, since the majority moved to urban areas for studies or career purposes. The shift in the use of NTFP has been also observed in other communities (Benz et al. 2000, Reyes-García et al. 2005) and can be explained by the proximity to urban centers and changes in lifestyle (Reyes-García et al. 2014).

The land is too small. I cannot live here. I cannot share the land with my father (Male, 27 years old).

Buriti stalks and leaves are widely used by many northern, northeastern, and mid-western Brazilian communities for household or commercial use (Santos \& Coelho-Ferreira 2012). In Abaetetuba City, Pará State, toys made of buriti stalks are commercialized all year round, but especially during the annual Círio de Nazaré festival. Immature leaves (buriti eye) are used to make linen for bags, rugs, tapes (known as 'mamucabos'), mats, belts, hats, and many other locally and internationally commercialized artifacts (Santos \& Coelho-Ferreira 2012). Indigenous and local communities in Mato Grosso State commercialize the linen and some of the products; however, there are no studies recording these commercial activities. 
Informants reported seven different stalk and leaf uses divided into two handicraft categories (Table 2); however, the main uses were six, because building was only mentioned by a single informant (Table 1). Despite being aware of buriti stalk and leaf usages, only five informants used buriti stalks and leaves to manufacture sieves, special sieves (known as "apá"), wickerwork, and roofs for pleasure or personal use. The low number of individuals could be explained by the lack of knowledge or the ease of purchasing industrialized products with the same function.

I wanted to learn, but when you get older, everything gets harder. When I was a child, I preferred modernity and easiness (Female, 51 years old).

I like apá made from buriti, because it is better for separating the rice. It is a pity that I did not learn from those who knew how to make it. Nowadays, there are only a few people who still make it. I only know a woman, who does, but she lives far from here, and I am too old to learn (Female, 55 years old).

Now it is easier to go to the city and buy it. It is not necessary to make it anymore. It is very hard work (Female, 45 years old).

Table II. Pi Values of each person, highlight the individual of knowledge and Uses of each one in the group.

\begin{tabular}{llllllll}
\hline Informant & Community & Gender & Age & Knowledge Quantity & Pi Value (Knowledge) & Use Quantity & Pi Value (Use) \\
\hline 2 & Manga & Male & 83 & 6 & 0.40 & 5 & 0.33 \\
\hline 4 & Manga & Male & 55 & 5 & 0.33 & 1 & 0.07 \\
6 & Retiro & Male & 82 & 5 & 0.33 & 0 & 0.00 \\
13 & Boqueirao & Male & 47 & 5 & 0.33 & 0 & 0.00 \\
18 & City & Male & 76 & 5 & 0.33 & 0 & 0.00 \\
1 & Manga & Male & 43 & 4 & 0.27 & 0 & 0.00 \\
3 & Retiro & Male & 50 & 4 & 0.27 & 0.00 \\
11 & Retiro & Male & 56 & 4 & 0.27 & 0.00 \\
22 & Retiro & Male & 64 & 4 & 0.27 & 1 & 0.07 \\
5 & Boqueirao & Male & 57 & 3 & 0.20 & 0.00 \\
12 & Retiro & Female & 51 & 3 & 0.20 & 0 & 0.07 \\
19 & Retiro & Male & 61 & 3 & 0.20 & 0 & 0.00 \\
20 & Boqueirao & Male & 50 & 3 & 0.20 & 0 & 0.00 \\
21 & Boqueirao & Male & 60 & 3 & 0.20 & 0 & 0.00 \\
7 & Retiro & Male & 59 & 2 & 0.13 & 0 & 0.00 \\
8 & Retiro & Female & 61 & 2 & 0.13 & 0 & 0.00 \\
9 & Retiro & Female & 62 & 2 & 0.13 & 1 & 0.07 \\
15 & Boqueirao & Male & 53 & 2 & 0.13 & 0 & 0.00 \\
17 & City & Male & 71 & 2 & 0.13 & 0 & 0.00 \\
23 & Boqueirao & Female & 58 & 2 & 0.13 & 0 & 0.00 \\
\hline 10 & Retiro & Female & 50 & 1 & 0.07 & 0 & 0.00 \\
14 & Boqueirao & Male & 59 & 0 & 0.00 & 0 & 0.00 \\
16 & Boqueirao & Female & 73 & 0 & 0.00 & 0.00 \\
\hline & & & & Total & 4.67 & 0.60
\end{tabular}

Buriti stipe is used by some riverine communities in Abaetetuba, Pará for building houses, bridges, and ports (Barros \& Da Silva 2013). In this study, informants mentioned five different uses of stipe (handicraft, 70\%; building, 14\%; food, 12\%; animal feed, $2 \%$; and ornamental, $2 \%$ ); however, they did not use this part anymore.

Nowadays, we build our houses using bricks and cement. It is easier. We do not use natural resources anymore, because it is too hard (Male, 47 years old).

In this study, ID was 4.67 (21 informants), relatively low compared with that reported in previous studies on the use of buriti leaves (ID = 35.8; 45 informants; Santos \& Coelho-Ferreira 2012), Attalea speciosa Mart., and Attalea eichleri (Drude) A. J. Hend. (ID = 22.89 and 10.35, respectively - 25 informants, González- 
Pérez et al. 2012). The low value could be explained by the low number of informants that use buriti (five out of 23 informants) and also the low number of uses (three out of 15 known uses). When we calculated ID including only the informants that actively use buriti, the value was not higher than 0.60 (Table 2). Therefore, it becomes clear that various production techniques may disappear in a short time, if no knowledge preservation action is taken.

The increase in the per capita income, mainly due to milk production funded by municipal programs, probably persuaded the informants to accept that modernization was necessary and buriti use obsolete. Informants showed little interest in learning production techniques due to field work and migration to urban environments, looking for better life conditions. Mccarter \& Gavin (2014) reported that the loss of TEK can be caused by the society, since the maintenance of knowledge requires joint efforts.

We used to make these products, because we did not have the money to buy them. But when we started making money, we do not need them anymore. Going to the city is easy now. There are buses or rides every day (Male, 51 years old).

We did not learn from our parents. They really knew how to make everything using buriti and other palm trees, but we do not. We are able to buy everything, and it is easier this way (Female, 39 years old).

Knowledge and cultural transmission are influenced by family relations and passes through the generations (Berkes 1999). In Quilombola communities, several difficulties led to the lack of knowledge on buriti uses and production techniques. Figure 2 shows the differences between the knowledge and current uses of buriti.

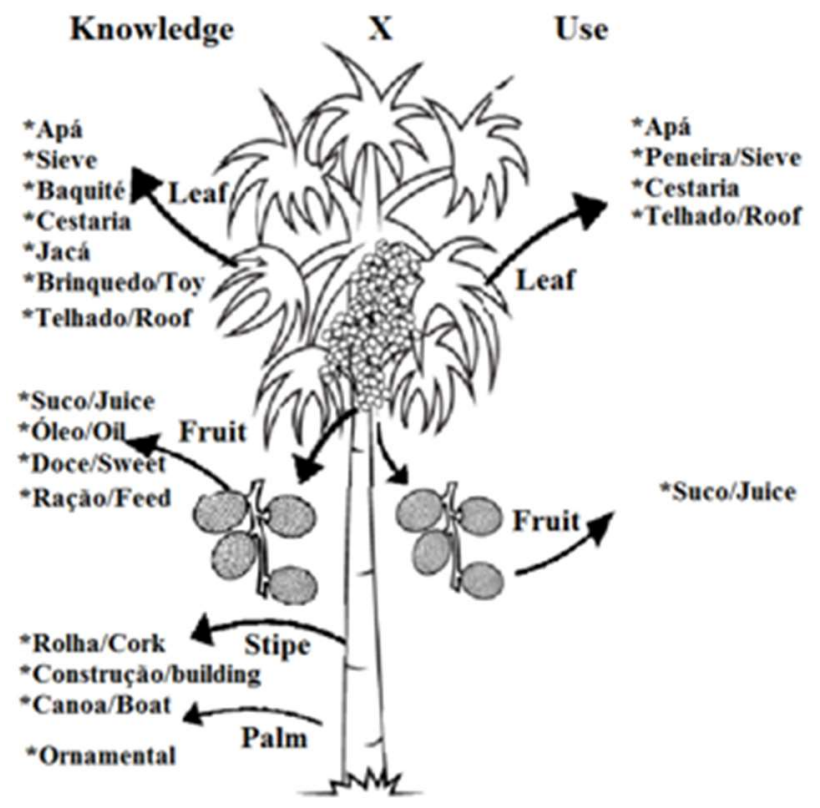

Figure 2. Comparative illustration of the known and active uses of buriti (Mauritia flexuosa L. f.) parts by three quilombola communities (Boqueirão, Retiro, and Casalvasco and Manga) in Vila Bela de Santíssima Trindade.

The use of NTFP followed the economic cycle of expansion, stabilization, and decline (Homma 1992). Some important NTFP can include an additional phase, the cultivation. While the buriti is used in many traditional communities in Brazil for subsistence purpose, there are important industrial uses. For example, the oil of the palm is widely used for cosmetic purpose and there are biotechnology purpose, all from natural populations, because it is found abundantly in nature. In this study, the economic role of buriti was almost 
zero, whereas the self-subsistence importance was relatively high (Table 3 ). The results revealed that the loss of TEK also occurs when natural products are substituted by industrial ones. Thus, the sustainable use of NTFP and the maintenance of cultural values are crucial, despite the negative economic impact (Koolen et al. 2013).

Table III. Illustrative summary of produced handicraft items made of buriti (Mauritia flexuosa L. f.) with a short description and usage information.

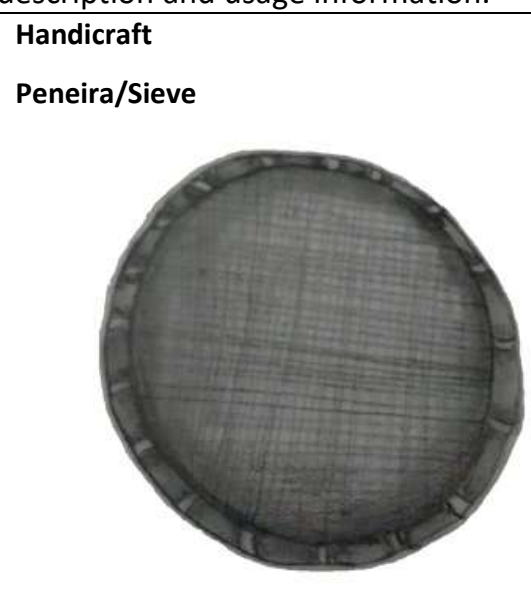

Apá

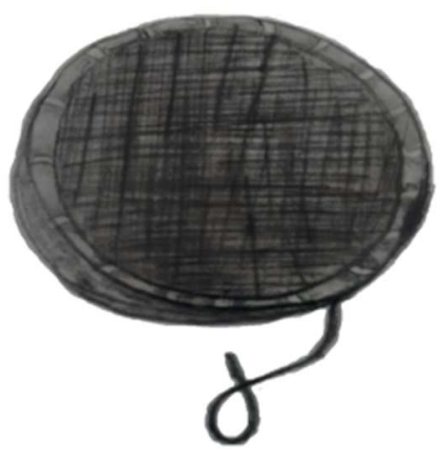

Baquité

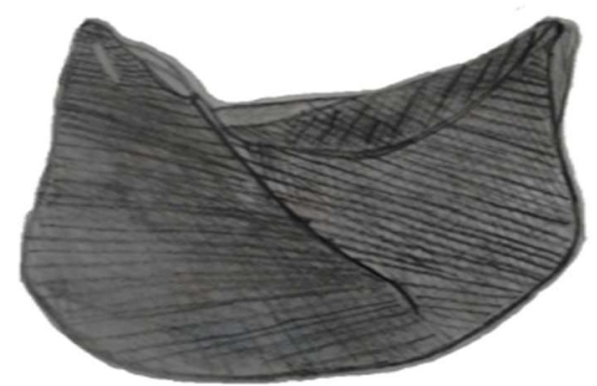

Cestaria

\section{Description}

Circular utensil, made of buriti leaf petiole fiber, attached to a bamboo arc with small cracks between the lines with an average radius of $41 \mathrm{~cm}$.

\section{Usage}

Used to separate parts with different thickness-in the studied communities, widely used to separate samp from fine flour.
Utensil similar to the sieve. The fibers are disposed without any space between them.
To select and/or separate groceries (rice, bean, corn, and coffee) by using the ventilation process, since the utensil does not allow the food to pass through it.
A basket made of buriti leaf lobe, braided according to the craftsman's preference or its goal.
Used to carry animals. When the product is damaged, it is used as chicken nest.

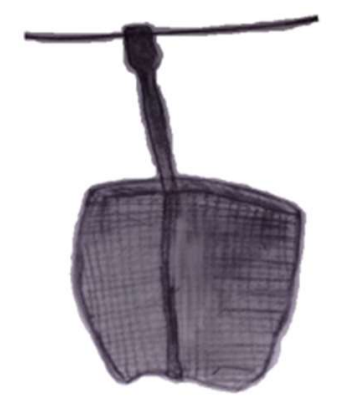

Made of buriti leaf lobes.
Used as flower basket, fruit bowl, and laundry basket. 
Jacá

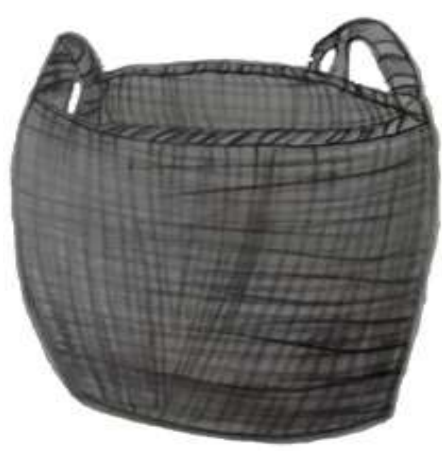

Brinquedo/Toy

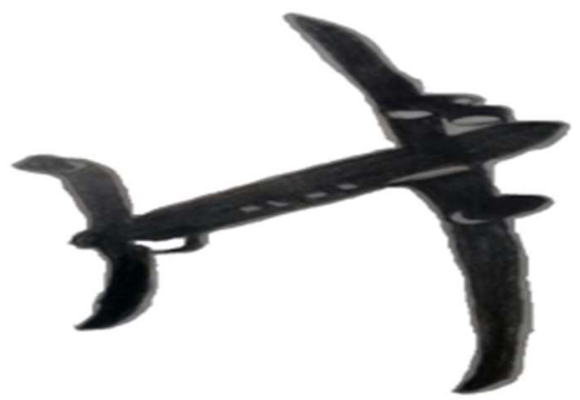

Rolha/Cork

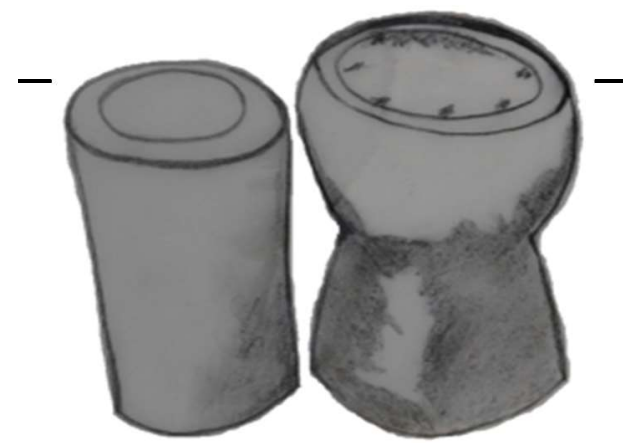

Made of the fiber that covers buriti leaf petiole. It has a cylindrical shape, with or without handles and varies in size.
Used to carry farm groceries: corn, cassava, bananas, and other products that could be carried on the back of a bull, horse, or people.
Made of leaf petiole. The craftsman can turn it into different types of toys and objects.
Used to make a wide range of toys, from animals to utensils, and other objects.
Utensil made of the buriti leaf petiole, which provides a soft and light material.
The stoppers are used to cover bottles and locally to cover "canjinjim" (a typical regional alcoholic liquor) bottles.

The results supported our hypothesis suggesting that TEK associated with Mauritia in Vila Bella is eroded by diverse drivers promoted by globalization. The tendency could be different in more remote places. It is critical to understand the extension where the disuse of NTFP and loss of associated TEK is occurring. It is a very important phenomenon to analyze and revert their tendency because the sustainable harvest of NTFP is one of the main alternatives to avoid deforestation.

\section{CONCLUSIONS}

This study showed that the use of buriti has been decreased, since the communities reside close to urban centers, and their economy has been influenced by the local market. The relatively low ID values revealed that the increase in the per capita income had a negative influence on the use of NTFP and the traditional knowledge. The ecological and cultural importance of buriti in the Quilombola communities is well 
known, and consequently, it is important to assure that knowledge and traditional practices will ally with the socioeconomic benefits of rural/urban connection.

ACKNOWLEDGEMENTS: To Quilombola community of Vila Bela, especially Ms Modesta Leite Ribeiro for receiving and affection, is already part of my family. To Michelly Leal Sander to make them so realistic and faithful drawings. Capes for granting master's scholarship to the student. The project "Knowledge, and Sustainable Use of Biodiversity Bioprospecting of Southern Amazon" n.554330 / 2010-5, CNPq, contribution n.5.

\section{REFERENCES}

ARRUDA, J.C. 2013. Conhecimento ecológico, usos e manejo de palmeiras pelos Quilombolas de Vila Bela da Santíssima Trindade, Mato Grosso Brasil. Dissertation, Universidade do Estado de Mato Grosso, Mato Grosso, 2011.

ARRUDA, J. C.; Da Silva, C. J.; SANDER, N. L.; BARROS, F. B. Traditional Ecological Knowledge of palms by quilombolas communities on the Brazil-Bolívia border, Meridional Amazon. Novos Cadernos NAEA, Belém, v. 17, n. 2, p. 123140, 2014. DOI: http://dx.doi.org/10.5801/ncn.v17i2.1810

BENZ, B.F., CEVALLOS, J., SANTANA, F., J. ROSALES \& S. GRAF. 2000 Losing knowledge about plant use in the Sierra de Manantlan biosphere reserve, Mexico. Economic Botany v. 54, n. 2, p. 183-191, 2000. DOI:

https://doi.org/10.1007/BF0290782

BERKES, F. Sacred ecology: traditional ecological knowledge and resource management Taylor and Francis. Science and the St Elia, London, 1999.

BERKES, F., FOLKE, C.; COLDING, J. Linking social and ecological systems: management practices and social mechanisms for building resilience. Cambridge University Press, Cambridge, 2000.

BERNARD, H.R. Research methods in anthropology: Qualitative and quantitative approaches. Rowman, Altamira, 2006.

BARROS, F.B.; DA SILVA, D. Os mingauleiros de miriti: trabalho, sociabilidade e consumo na beira de Abaetetuba, Pará. Revista FSA v. 10, n. 4, 2013. DOI: http://dx.doi.org/10.12819/2013.10.4.3

BYG, A.; BALSLEV, H. Diversity and use of palms in Zahamena, eastern Madagascar. Biodiversity \& Conservation. v. 10, n. 6, p. 951-970, 2001. DOI: https://doi.org/10.1023/A:1016640713643

BYG, A.; BALSLEV, H. Palms in indigenous and settler communities in southeastern Ecuador: farmers' perceptions and cultivation practices. Agroforestry Systems v. 67, n. 2, p. 147-158, 2006. DOI: https://doi.org/10.1007/s10457-005$\underline{1704-1}$

CARRERA, L. Aguaje (Mauritia flexuosa) a promising crop of the Peruvian Amazon. In: II ISHS Conference on Fruit
Production in the Tropics and Subtropics 531. 1999. p. 229236.

CORADÍN, L.; LLERAS, E. Overview of palm domestication in Latin America. Advances in Economic Botany. v. 6, p. 175189, 1988.

DELGADO, C.; COUTURIER, G.; MEIJA, K. Mauritia flexuosa L.f. (Arecaceae: Calamoideae), an Amazonian palm with cultivation purposes in Peru. Fruits v. 62, n. 3, p. 157-169, 2007. DOI: https://doi.org/10.1051/fruits:200701

FERNANDES, C.R. O que queriam os Kalungas? A transformação do olhar acadêmico sobre as demandas quilombolas do nordeste de Goiás. Interações 16:421-431. v. 16, n. 2, 2015.

DOI: http://dx.doi.org/10.20435/interações.v16i2.79

GEERTZ, C.A. Interpretação das culturas. Editora Guanabara, Rio de Janeiro. 1989.

GILMORE, M. P.; ENDRESS B. A.; HORN, C. M. 2013. The socio-cultural importance of Mauritia flexuosa palm swamps (aguajales) and implications for multi-use management in two Maijuna communities of the Peruvian Amazon. Journal of ethnobiology and ethnomedicine. v. 9, n. 1, p. 29, 2013. DOI: https://doi.org/10.1186/1746-4269-9-29

GÓMEZ-BAGGETHUN, E.R.I.K., MINGORRÍA, S.; REYESGARCÍA, V.; CALVET, L.; MONTES, C. Traditional ecological knowledge trends in the transition to a market economy: empirical study in the Doñana natural areas. Conservation Biology v. 24, n. 3, p. 721-729, 2010.APA. DOI: http://doi.org/10.1111/j.1523-1739.2009.01401.x

GONZÁLEZ-PÉREZ, S.E.; COELHO-FERREIRA, M.; ROBERT, P.D.; GARCÉS, C.L.L. Conhecimento e usos do babaçu (Attalea speciosa Mart. e Attalea eichleri (Drude) AJ Hend.) entre os Mebêngôkre-Kayapó da Terra Indígena Las Casas, estado do Pará, Brasil. Acta Botanica Brasilica v. 26, n. 2, p. 295-308, 2012. DOI: http://dx.doi.org/10.1590/S0102$\underline{33062012000200007}$

GRAY, C. L.; BILSBORROW, R. E.; BREMNER, J. L.; LU, F. Indigenous land use in the Ecuadorian Amazon: a crosscultural and multilevel analysis. Human Ecology v. 36, n. 1, p. 97-109, 2008. DOI: https://doi.org/10.1007/s10745-007$\underline{9141-6}$ 
HANAZAKI, N. Comunidades, conservação e manejo: o papel do conhecimento ecológico local. Biotemas v. 16, n. 1, p. 2347, 2003. DOI: https://doi.org/10.5007/\%25x

HOMMA, A.K. 1992. The dynamics of extraction in Amazonia: a historical perspective. Advances in Economic Botany. v.9. p.23-23. 1992.

HORN, C.M.; GILMORE, M.P.; ENDRESS, B.A. 2012. Ecological and socio-economic factors influencing aguaje (Mauritia flexuosa) resource management in two indigenous communities in the Peruvian Amazon. Forest ecology and management. v. 267, p. 93-103, 2012. DOI: https://doi.org/10.1016/j.foreco.2011.11.040

IBGE, Instituto Brasileiro de Geografia e Estatística (2015) Produção da Pecuária Municipal 2014. Accessed 10 January 2015.

KOOLEN, H.H., DA SILVA, F.M.; DE SOUZA-GOZZO A.Q.; DE SOUZA, A. D. Antioxidant, antimicrobial activities and characterization of phenolic compounds from buriti (Mauritia flexuosa L. f.) by UPLC-ESI-MS/MS. Food research international v. 51, n. 2, p. 467-473, 2013. DOI: https://doi.org/10.1016/j.foodres.2013.01.039

LEITMAN, P.; HENDERSO, A.; NOBLICK, N. L.; MARTINS, R. C.; SOARES, K. ARECACEAE in Lista de Espécies da Flora do Brasil. Jardim Botânico do Rio de Janeiro, 2016.

LITRE, G., NASUTI, S.; GARCEZ, C.A.G.; LINDOSO, D.P.; EIRÓ, F.; SIMONI, J.; DA SILVA, C.J.; FAÇANHA, C.L. From Rainforests to Drylands: Comparing Family Farmers Perceptions of Climate Change in Three Brazilian Biomes. In: Filho WL, Alves F, Caeiro S, Azeiteiro UM (eds) International Perspectives on Climate Change. Springer International Publishing, Switzerland. 2014

LORENZI, H., NOBLICK, L.; KAHN, F.; FERREIRA, E. Flora Brasileira: Arecaceae (Palmeiras). Instituto Plantarium, Nova Odessa, São Paulo.

MANZI, M.; COOMES, O.T. Managing Amazonian palms for community use: a case of aguaje palm (Mauritia flexuosa) in Peru. Forest Ecology and Management, v. 257, n. 2, p. 510517, 2009. DOI:

https://doi.org/10.1016/j.foreco.2008.09.038

MCCARTER, J.; GAVIN, M.C. Local perceptions of changes in traditional ecological knowledge: a case study from Malekula Island, Vanuatu. Ambio, v. 43, n. 3, p. 288-296, 2014. DOI: https://doi.org/10.1007/s13280-013-0431-5

MARTINS, R.C.; FILGUEIRAS, T.S.; DE ALBUQUERQUE, U.P. Ethnobotany of Mauritia flexuosa (Arecaceae) in a maroon community in central Brazil. Economic Botany, v. 66, n. 1, p. 91-98, 2012. DOI: https://doi.org/10.1007/s12231-0119182-z

MILANESI, L.S.; PERONI, N; DOS REIS, M. Use of the palm Euterpe edulis Martius in landscape units managed by migrants of German origin in Southern Brazil. Journal of ethnobiology and ethnomedicine. v. 9, n. 1, p. 47, 2013. DOI: https://doi.org/10.1186/1746-4269-9-47

PALMARES, Fundação Cultural: Comunidades Quilombolas, 2016.
PULIDO, M.T.; CAVELIER, J. Comercialización de productos vegetales no maderables en los mercados de Leticia y Florencia, Amazonia colombiana. Evaluación de recursos vegetales no maderables en la Amazonía noroccidental. Amsterdam: IBED: 265-310. 2001.

PULIDO, M.T.; CORONEL-ORTEGA, M. Ethnoecology of the palm Brahea dulcis (Kunth) Mart. in central Mexico. Journal of Ethnobiology and Ethnomedicine, v. 11, n. 1, p. 1, 2015. DOI: http://doi.org/10.1186/1746-4269-11-1

RADAMBRASIL . Levantamento de Recursos Naturais, Folha SD.23 Brasília: geologia, geomorfologia, pedologia, vegetação e uso potencial da terra. Rio de Janeiro: Ministério de Minas e Energia. Secretaria Geral, v. 29, Rio de Janeiro. 1982.

REYES-GARCIA, V., BYRON, E.; APAZA, L.; VADEZ, V.; WILKIE, D.; PEREZ, E.; LEONARD, W.R. Market economy and the loss of folk knowledge of plant uses. Current Anthropology. v. 46, n. 4, p. 651-656, 2005. DOI: https://doi.org/10.1086/432777

REYES-GARCÍA, V.; GUÈZE, M.; LUZ, A.C.; PANEQUE-GÁLVEZ, J.; MACÍA, M.J.; ORTA-MARTÍNEZ, M.; PINO, J.; RUBIOCAMPILLO, X. Evidence of traditional knowledge loss among a contemporary indigenous society. Evolution and Human Behavior v. 34, n. 4, p. 249-257, 2013. DOI: https://doi.org/10.1016/j.evolhumbehav.2013.03.002

REYES-GARCÍA, V.; PANEQUE-GÁLVEZ, J.; LUZ, A.; GUEZE, M.; MACÍA, M.; ORTA-MARTÍNEZ, M.; PINO, J. Cultural Change and Traditional Ecological Knowledge: An Empirical Analysis from the Tsimane'in the Bolivian Amazon. Human Organization v. 73, n. 2, p. 162-173, 2014. DOI: https://doi.org/10.17730/humo.73.2.31nl363qgr30n017

RICHARDSON, R.J.; DE SOUSA PERES, J.A. Pesquisa social: métodos e técnicas', Atlas. São Paulo. 1999.

SALLES, V. O negro no Pará: Sob 0 regime da escravidão. Fundação Getúlio Vargas, Universidade Federal do Pará, Pará. 1971.

SANTOS, G.M.; ANTONINI, Y. The Traditional Knowledge on Stingless Bees (Apidae: Meliponina) Used by the EnaweneNawe Tribe in western Brazil. Journal of Ethnobiology and Ethnomedicine. v. 4, n. 1, p. 19, 2008. DOI: https://doi.org/10.1186/1746-4269-4-19

SANTOS, R.D.S.; COELHO-FERREIRA, M. Artefatos de miriti (Mauritia flexuosa L. f.) em Abaetetuba, Pará: da produção à comercialização. Boletim do Museu Paraense Emílio Goeldi v. 1, n. 1, p. 559-571, 2011.

SANTOS, R.D.S.; COELHO-FERREIRA, M. Estudo etnobotânico de Mauritia flexuosa L. f. (Arecaceae) em comunidades ribeirinhas do Município de Abaetetuba, Pará, Brasil. Acta Amazonica, v. 42,n. 1, p1-10, 2012.

SHACKLETON, C.M.; PANDEY, A.K. Positioning non-timber forest products on the development agenda. Forest Policy and Economics v. 38, p. 1-7, 2014. DOI: https://doi.org/10.1016/i.forpol.2013.07.004 
TER STEEGE, T., PITMAN, N.C.A.; SABATIER, D.; BARALOTO, C.; SALOMÃO, R.P.; GUEVARA, J.E.; PHILLIPS, O.L.; CASTILHO, C.V.; MAGNUSSON, W.E.; MOLINO, J.F.; MONTEAGUDO, A.; VARGAS, P.N.; MONTERO, J.C.; FELDPAUSCH, T.R.; CORONADO, E.N.H.; KILLEEN, T.J.; MOSTACEDO, B.; VASQUEZ, R.; ASSIS, R.L.; TERBORGH, J.; WITTMANN, F.; ANDRADE, A.; LAURANCE, W.F.; LAURANCE, S.G.W.; MARIMON, B.S.; MARIMON JR, B.H.; VIEIRA, I.C.G.; AMARAL, I.L.; BRIENEN, R.; CASTELLANOS, H.; LÓPEZ, D.C.; DUIVENVOORDEN, J.F.; MOGOLLÓN, H.F.; MATOS, F.D.A.; DÁVILA, N.; GARCÍA-VILLACORTA, R.; DIAZ, P.R.S.; COSTA, F.; EMILIO, T.; LEVIS, C.; SCHIETTI, J.; SOUZA, P; ALONSO, A.; DALLMEIER, F.; MONTOYA, A.J.D.; PIEDADE, M.T.F.; ARAUJOMURAKAMI, A.; ARROYO, L.; GRIBEL, R.; FINE, P.V.A.; PERES C.A.; TOLEDO M., AYMARD, C.; BAKER, T.R.; CERÓN, C.; ENGEL, J.; HENKEL, T.W.; MAAS, P.; PETRONELLI, P.; STROPP, J.; ZARTMAN, C.E.; DALY, D.; NEILL, D.; SILVEIRA, M.; PAREDES, M.R.; CHAVE, J.; FILHO, D.A.L.; JØRGENSEN, P.M.; FUENTES, A.; SCHÖNGART, J.; VALVERDE, F.C.; FIORE, A.D.; JIMENEZ, E.M.; MORA, M.C.P.; PHILLIPS, J.F.; RIVAS, G.; VAN ANDEL, T.R.; VON HILDEBRAND, P.; HOFFMAN, B.; ZENT, E.L.; MALHI, Y.; PRIETO, A.; RUDAS, A.; RUSCHELL, A.R.; SILVA, N.; VOS, V.; ZENT, S.; OLIVEIRA, A.A.; SCHUTZ, A.C.; GONZALES, T.; NASCIMENTO, M.T.; RAMIREZ-ANGULO, H.; SIERRA, R.; TIRADO, M.; MEDINA, M.N.U.; VAN DER HEIJDEN, G.; VELA,
C.I.A.; TORRE, E.V.; VRIESENDORP, C.; WANG, O.; YOUNG, K.R.; BAIDER, C.; BALSLEV, H.; FERREIRA, C.; MESONES, I.; TORRES-LEZAMA, A.; GIRALDO, L.E.U.; ZAGT, R.; ALEXIADES, M.N.; HERNANDEZ, L.; HUAMANTUPA-CHUQUIMACO, I.; MILLIKEN, W.; CUENCA, W.P.; PAULETTO, D.; SANDOVAL, E.V.; GAMARRA, L.V.; DEXTER, K.G.; FEELEY, K.; LOPEZGONZALEZ, G.; SILMAN, M.R. 2013. Hyperdominance in the Amazonian tree flora. Science, v. 342, n. 6156, p. 1243092, 2013. DOI: http://doi.org/10.1126/science.1243092

THE WORLD BANK. Implementation Completion Report (CPL34920) on a Loan in the Amount of US\$205.0 million to the Federative Republic of Brazil for a Mato Grosso Natural Resources Management (LOAN 3492-BR), 2003.

THORKILDSEN, K. Social-Ecological Changes in a Quilombola Community in the Atlantic Forest of Southeastern Brazil. Human Ecology v. 42, n. 6, p. 913-927, 2014. DOI: https://doi.org/10.1007/s1074

VOLPATO, L.R.R. 1996. Quilombos em Mato Grosso: resistência negra em área de fronteira. In. REIS, J. J. \& GOMES, F. S.. Liberdade por um fio: história dos Quilombos no Brasil. Sao Paulo: Companhia das Letras, São Paulo, 1996.

A CBPC - Companhia Brasileira de Produção Científica (CNPJ: 11.221.422/0001-03) detém os direitos materiais desta publicação. Os direitos referem-se à publicação do trabalho em qualquer parte do mundo, incluindo os direitos às renovações, expansões e disseminações da contribuição, bem como outros direitos subsidiários. Todos os trabalhos publicados eletronicamente poderão posteriormente ser publicados em coletâneas impressas sob coordenação da Sustenere Publishing, da Companhia Brasileira de Produção Científica e seus parceiros autorizados. Os (as) autores (as) preservam os direitos autorais, mas não têm permissão para a publicação da contribuição em outro meio, impresso ou digital, em português ou em tradução. 